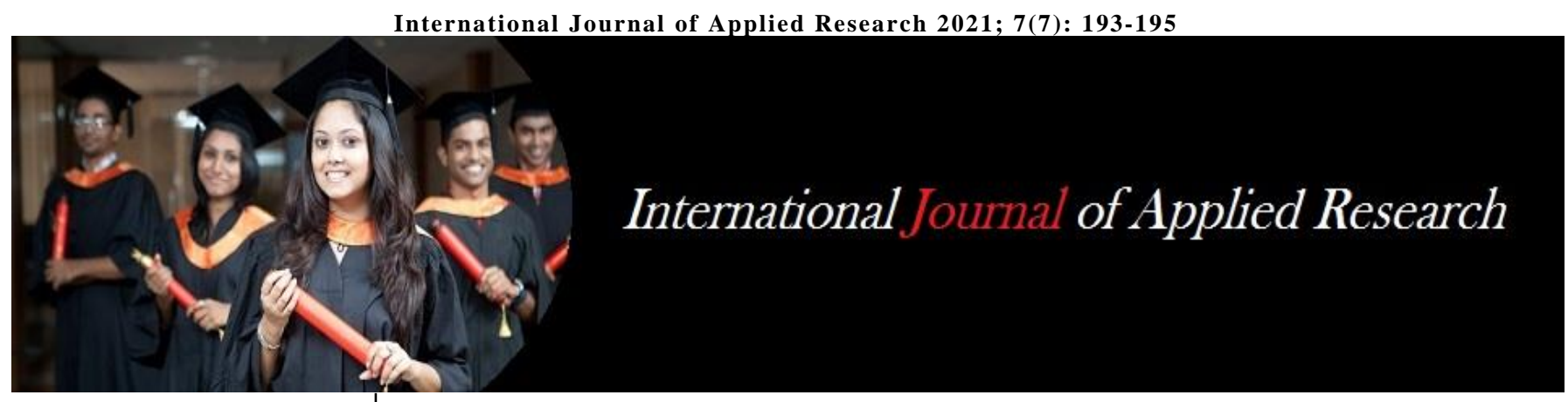

ISSN Print: 2394-7500 ISSN Online: 2394-5869 Impact Factor: 8.4 IJAR 2021; 7(7): 193-195 www.allresearchjournal.com Received: 24-04-2021 Accepted: 29-05-2021

Richa Langyan Assistant Professor, Department of English, RKSD (Post Graduate) College, Kaithal, Haryana, India
Corresponding Author: Richa Langyan Assistant Professor, Department of English, RKSD (Post Graduate) College, Kaithal, Haryana, India

\section{Author and text: A critical analysis of Michel Foucault's what is an author}

Richa Langyan

DOI: https://doi.org/10.22271/allresearch.2021.v7.i7c.8753

\section{Abstract}

Michel Foucault (1926-84) was a philosopher, social scientist and historian of ideas. He died as professor of the History of Systems of thought at the college De France in Paris. He has exerted an enormous influence on many branches of thoughts in the later twentieth century, including what is broadly known as 'Cultural Studies'. The paper aims to highlight that he has a seminal impact on the New Historicism that was initiated by Stephen Greenblatt, as well as on queer theory. The central theme of most of Foucault's works is "the methods with which modern civilization creates and controls human subjects through institutions such as hospitals, prisons, education, and knowledge. The corollary to these investigations was Foucault's examination of power, its execution and distribution" (Habib, 766). His works offer a characterization of the growth of knowledge in the modern western world as manifested in the emergence of disciplines such as linguistics, economies and biology.

Keywords: Author, text, literary criticism, history, structuralism, Michel Foucault

\section{Introduction}

Foucault's essay, 'What is an Author?' presents a masterly study of the concept of authorship where he argues that analysis of literary texts cannot be restricted to the texts themselves or to their author's psychology and background. Rather the larger contexts and cultural conventions in which texts are produced are necessary to be taken into consideration. Foucault, in the essay, observes the fundamental role that the notion of author occupies in the institution and practice of literary criticism. In fact, the "man and his work" is a "fundamental critical category." Foucault points out two tendencies in recent writing which protest against this exaltation of the author. The first exemplified by writers such as Brecht, is a view of writing as free from the necessity of expression, from the need to express the thoughts and emotions of an individual. This reversal, says Foucault, "transforms writing into interplay of signs, regulated less by the contents it signifies than by the very nature of the signifier" (Lodge, 193). Foucault is now beginning to sound like a post structuralist. The second theme is the "kinship between writing and death". Traditionally, writing (as in epic narratives) has been viewed as a means of overcoming death, of achieving immortality by recording heroic and noble actions. But our culture has transformed this conception of writing as "a protection against death". Writing is now a voluntary obliteration of the self, and effects a total effacement of the individual characteristics of the writer, and in this way canceling out the signs of his particular individuality. Writing creates an opening where "the writing subject endlessly disappears" (Lodge, 193).

Foucault observes that the consequences of Barthes' proclamation of "the death of the author" have not been fully explored, largely due to two developments. The first of these might be attributed to formalistic, New Criticism and certain structuralist approaches: a position that effectively replaces the privileged position of the author with an equally privileged status of the work. This perspective sees criticism as concerned with "the structures of a work, its architectonic forms, which are studied for their intrinsic and internal relationship" (Lodge, 193). But, Foucault argues, if we are rejecting the term "author" as designating some coherent entity systematically grounding the text, we must equally reject any simple definition of the "work" as a unitary entity. 
The second notion that has impeded a proper examination of the author's disappearance is that of ecriture, or writing, where this term implies a signifying system constituted by relation and difference, embodying a rejection of the notion of simple, self-contained identity. While Foucault acknowledges that this notion stands for a remarkably profound attempt to elaborate the conditions of any text, he charges it with subtly perpetuating the existence of the author. This post-structuralist notion of writing, says Foucault, has "merely transposed the empirical characteristics of an author to a transcendental anonymity" (Lodge, 194).

Foucault in the essay tries to clarify briefly the problems arising from the use of the author's name. The name of the author is, first of all, a proper name, a signifier that designates a specific and discrete historical individual (just as our names designate us as specific historical individuals). But an author's name does more than that; when we say "Aristotle", or "Shakespeare" we mean more than just the guy who lived - we also mean the thoughts he is attributed with, the mode of thinking, the objects of contemplation, the methodology, or the writing associated with that name.

The proper name of an author, according to Foucault, oscillates between two poles-between designation, which refers to the person, and description, which refers to the ideas/work, associated with the name. Designation and description are not the same, not isomorphic. The proper name as a signifier can have either the signified of the actual person or the signified of the work/ideas. In each case, the relation between signifier and signified - between proper name and what it either designates or describes - is arbitrary and separable. For instance, "Shakespeare" can refer to the guy who lived in Stratford-on-Avon in the seventeenth century, or it can refer to the numerous plays and poems linked under the name "Shakespeare". The idea of the separability of designation and description becomes clear when someone argues that Shakespeare did not write the plays of Shakespeare meaning that the historical figure is not actually the guy responsible for the body of works called "the plays of Shakespeare". Such a sentence makes sense only if "Shakespeare" signifies two separate things.

This shows that the author's name serves as a means of identification, not simply as an element of speech. The name, "Shakespeare" groups together a number of texts and differentiates them from others: Shakespeare marks what is not George Eliot and what is not T.S Eliot etc. The author's name, according to Foucault, characterizes a particular manner of existence of discourse; the texts attributed to an author are given more status, more attention and more cultural value than texts which have no author. Foucault states here:

An anonymous text posted on a wall probably has a writer but not an author. The author's function is therefore characteristic of the mode of existence, circulation of functioning of certain discourses within a society. (Lodge, 197)

At this point, "Foucault's concern was also post structuralist because, like Derrida and others, Foucault posited a subject as constituted by discourse" (Nayar, 60).

\section{Findings}

Foucault characterizes discourse which contains authorfunction and notes four crucial features of author-function. First, discourses are objects of appropriation, forms of property. Speeches and books were assigned to real authors only when the authors became subjected to punishment for what the speech or book said. When the writing/speech said something transgressive, something that broke rules, then systems of authority had to find some locus from which the transgressive speech came; the cops and courts had to find someone to punish. Foucault's example is that of a heresy: when heresy was uttered, there had to be a heretic behind the utterance, since you cannot punish words or ideas. From this idea of locating authorship in someone held responsible for writing or speech came also the idea of authorship of works, the idea of copyright rules associated with ownership. As Foucault points out:

In our culture (and doubtless in many others), discourse was not originally a product, a thing, a kind of goods; it was essentially an act- an act placed in the bipolar field of the sacred and profane, the licit and the illicit, the religious and the blasphemous. Historically, it was a gesture fraught with risks before becoming goods caught up in a circuit of ownership. (Lodge, 197)

Secondly, the "author-function" is not universal or constant in all discourse. Even within our civilization, the same types of texts have not always required authors; there was a time when those texts which we call "literary" (stories, folk tales, epics and tragedies) were accepted, circulated and valorized without any questions about the identity of their author. Their anonymity was ignored because their real or supposed age was a sufficient guarantee of their authenticity. Text, however, that we now call "scientific" (dealing with cosmology and the heavens, medicine or illness, the natural sciences or geography) were only considered truthful during the middle ages if the name of the author was indicated. Statements like "Pliny says..." or "Hippocrates said..." were not merely formulas for an argument based on authority; they marked a proven discourse. In the seventeenth and eighteenth centuries, a totally new conception was developed when scientific texts were accepted on their own merits and positioned within an anonymous and coherent conceptual system of established truths and modes of versification.

At the same time, however, "literary" discourse was acceptable only if it carried an author's name; every text of poetry or fiction was obliged to state its author and the date, place, and circumstances of its writing. If by chance, a text was presented anonymously, every effort was made to locate its author. Literary anonymity was of interest only as a puzzle to be solved as in our day; literary works are totally dominated by the sovereignty of the author.

The third feature concerning this "author-function" is that it is not formed spontaneously through the simple attribution of a discourse to an individual. It results from a complex operation whose purpose is to construct the rational entity we call an author. Undoubtedly, this construction is assigned a "realistic" dimension as we speak of an individual's "profundity" or "creative" power, his intentions or the original inspiration manifested in writing. Nevertheless, these aspects of an individual, which we designate as an author, are only projections, in terms always more or less psychological, of our way of handling texts, in the connections we make, the traits we extract as pertinent, the continuities we assign or the exclusions we practice. In addition, all these operations vary according to the period and the form of discourse concerned. A "philosopher" and a "poet" are not constructed in the same manner; and the 
author of an eighteenth century novel was formed differently from the modern novelist.

The fourth and the final characteristic of discourse is that the text always bears signs that refer to the author or create the "author-function". As Foucault says:

The text always contains a certain number of signs referring to the author. These signs, well known to grammarians are personal pronouns, adverbs of time and place and verb conjugation. (Lodge, 199)

The most easily recognizable of these signs is a pronoun, "I", though we know better than to assume that the "I" of a narrator is identical to the "I" of an author. Foucault suggests that the author function arises out of the difference and separation, between the "author-function" and the writer signified in the text. This is most easily seen in narrative fiction, but is true to any form of discourse.

\section{Discussion}

Further, Foucault suggests that certain authors such as Homer, Aristotle, and the Church Fathers - occupy a "transdiscursive position": They authored not merely books but theories or traditions in which new works could proliferate. But Foucault sees the nineteenth century as having author, distinct from the founders of science or the authors of colonical religious texts: the initiator of a discursive practice. Marx and Freud, he says, are the prime examples of such initiating authors. They both "established the endless possibility of discourse" (Lodge, 201). Not only did they enable a certain number of concepts and analogies that could be adopted by future texts, but they also opened up a space for divergences from their own hypotheses.

At the end, Foucault distinguishes between the traditional meaning of author and what he means by author in clear-cut terms. Traditionally, we think that author is the genial creator of a work in which he deposits, with infinite wealth and generosity, an inexhaustible world of significations. We are used to thinking that the author is so different from all other men, and as he speaks meaning begins to proliferate indefinitely. But the truth is contrary as Foucault states:

The author is not an indefinite source of significations which fill a work. The author does not precede the work, he is a certain functional principle by which, in our culture, one limits, excludes, and chooses... The author is the ideological figure by which one marks the manner in which we fear the proliferation of meaning. (Lodge, 204)

\section{Conclusion}

Foucault ends his essay by expressing his doubt about the survival of "author-function" in the years to come and with a warning that it would give to the "anonymity of a murmur." At that point, new types of questions will arise such as: What are the modes of existences of this discourse?", What are the places in it where there is room for possible subjects?" (Lodge, 205). And behind all these questions we would hear the stirring of indifference: "What difference does it make who is speaking?" (Lodge, 205)

\section{References}

1. Moddelmog, Debra A. Reading Desire: In Pursuit of Ernest Hemmingway. Ithaca: Cornell University Press 1999. Print.

2. Myler, Kerry. "You Can't Judge a Book by its Coverage: The Body that Writes and the Television Book Club." The Richard \& Judy Book Club Reader:
Popular Texts and the Practices of Reading. Ed. Jenni Ramone. Surrey \& Burlington: Ashgate Publishing Company 2011. Print.

3. Hirsch ED. Validity in Interpretation. New Haven/London: Yale University Press 1967. Print.

4. Irwin, William. Internationalist Interpretation: A Philosophical Explanation and Defense.

5. Swann, Marjorie. Curiosities and Texts. Philadelphia: University of Pennsylvania Press 2001. Print.

6. Foucault, Michel. "What is an Author?" Language, Conreter-Memory, Practice. Ed. Donald F. Bouchard. Ithaca: CUP 1977, 113-138. Print.

7. Horton, Susan. Interpreting. Baltimore: John Hopkins 1979. Print.

8. Nehamas, Alexander. "What and Author Is." The Journal of Philosophy 83.11 1986, 685-691. Print.

9. Author and Text: Reading Michel Foucault's "What is an Author?". The Criterion: An International Journal of English 3, 1-11. 